\title{
Surgical cricothyroidostomy. Analysis and comparison between teaching and validation models of simulator models
}

\section{Cricotireoidostomia cirúrgica. Análise e comparação entre modelos de ensino e validação de simuladores}

Akinito Inca Atahualpa Urdiales, TCBC-PR $1,2,3$; Gabriela Tulio Struck4; Camila Roginski Guetter ${ }^{4}$; Cecilia Hissal Yaegashi ${ }^{5}$; Kassio Silva Temperly6; Phillipe Abreu, TCBC-PR (iD2); Flavio SaAvedra Tomasich, TCBC-PR2,7; Antônio Carlos Ligocki Campos, TCBC-PR 3,7

\section{A B S T R A C T}

\begin{abstract}
Objective: to compare the acquisition and retention of knowledge about surgical cricothyroidostomy by the rapid four-step technique (RFST), when taught by expository lecture, low fidelity and high-fidelity simulation models. Methods: ninety medical students at UFPR in the first years of training were randomized assigned into 3 groups, submitted to different teaching methods: 1) expository lectures, 2) low-fidelity simulator model, developed by the research team or 3 ) high-fidelity simulator model (commercial). The procedure chosen was surgical cricothyroidostomy using the RFST. Soon after lectures, the groups were submitted to a multiple-choice test with 20 questions (P1). Four months later, they underwent another test (P2) with similar content. Analysis of Variance was used to compare the grades of each group in P1 with their grades in P2, and the grades of the 3 groups 2 by 2 in P1 and P2. A multiple comparisons test (posthoc) was used to check differences within each factor (test and group). Statistical significance was considered when $p<0.05$. Statistical analysis was performed in the statistical software R version 3.6.1. Results: each group was composed of 30 medical students, without demographic differences between them. The mean scores of the groups of the expositive lecture, of the simulator of low fidelity model and of high-fidelity simulator model in P1 were, respectively, 75.00, 76.09, and 68.79, ( $p<0.05$ ). In P2 the grades were 69.84, 75.32, 69.46, respectively, $(p>0.05)$. Conclusions: the simulation of low fidelity model was more effective in learning and knowledge retention, being feasible for RFST cricothyroidostomy training in inexperienced students.
\end{abstract}

Keywords: Simulation Training. Education, Medical. Emergency Medicine. Airway Management. Cricoid Cartilage.

\section{INTRODUCTION}

M edical education has traditionally been based on teachings centered on teachers, reading scientific evidence and performing procedures on cadavers, animals or real patients ${ }^{1,2}$. In this teaching model, students acquire a satisfactory theoretical basis; however, there is a perception of lag in terms of practical experiences ${ }^{3}$. It is common for the first execution of a procedure to occur in real patients, which creates insecurity in the learner and risks to the patient ${ }^{3-5}$. In the last twenty years, new ethical concepts have emerged in the society, which have influenced health education. Situations like "learning by doing" or training in animals are not more acceptable in the most developed countries ${ }^{6,7}$. It is precisely in this educational dilemma, between the need for practical training and patient safety, that medical simulation fits ${ }^{8,9}$. Simulation is defined as the replacement or reproduction of real situations through scenarios carefully constructed to evoke interactive responses from the student ${ }^{2,8}$.

Teaching through simulation eliminates the use of cadavers and experimental animals, reduces costs and facilitates obtaining a sufficient number of events, in addition to addressing any ethical conflicts of training ${ }^{10,11}$. It provides students with an experience prior to the contact with the first patient in a controlled, safe environment, with review of eventual errors ${ }^{12}$. The individualized, repeated and continued training ensures greater efficiency in learning and consequently

1 - Hospital do Trabalhador/Federal University of Paraná, Department of Integrated Medicine - Curitiba - PR - Brazil 2 - Hospital do Trabalhador/Federal University of Paraná, Department of Surgery - Curitiba - PR - Brazil 3 - Federal University of Paraná, Postgraduate Program in Surgical Clinic - Curitiba $P R$ - Brazil 4 - Federal University of Paraná, Medical Course - Curitiba - PR - Brazil 5 - Cajuru University Hospital- Pontifical Catholic University of Paraná, Department of Surgery - Curitiba - PR - Brazil 6 - Pontifical Catholic University of Paraná, Course of Medicina - Curitiba - PR - Brazil 7 - Federal University of Paraná, Department of Surgery - Curitiba - PR - Brazil 
greater security for the student and the patient , 12-14 $^{\text {T Th }}$ advantage is more relevant in teaching infrequent surgical techniques, but which are essential for maintaining life, as is the case with surgical cricothyroidostomy ${ }^{15}$.

The difficulties in developing simulators able to faithfully reproduce the anatomy, tissue texture and possible anatomic variations or lesions to the decision making training made medical simulation evolve more slowly ${ }^{16,17}$. Recently, technological advances of software and synthetic materials were the basis for the development of high-fidelity simulators, much like a real patient ${ }^{18-20}$. The improvement in simulators occurred due to the large financial investment in research, which raised the final cost of high-fidelity simulation, hindering their large-scale deployment, particularly in developing countries ${ }^{2,19}$.

The low-cost alternative is the development of low-fidelity simulators with simple materials ${ }^{21,22}$. There are still questions about whether this strategy would be really effective in learning medical procedures and what is the degree of inferiority when compared with highfidelity apparatuse ${ }^{23}$.

There is still controversy in the literature regarding the difference in learning effectiveness when comparing simulators of different degrees of fidelity and what is the cost-benefit ratio of each method ${ }^{24-33}$.

Our objective was to evaluate the effectiveness of different teaching methods (lecture, low and high fidelity simulation) in the acquisition and retention of knowledge about surgical cricothyroidostomy by the Rapid Four-Step Technique (RFST) in inexperienced medical students.

\section{METHODS}

\section{Study design}

We conducted a prospective, randomized, comparative study, approved by the Ethics Committee for Research on Human Beings of the Hospital do Trabalhador - SES/PR, under number CAAE 63022116.4.0000.5225, approval opinion 1,905,794. All voluntary research participants signed an informed consent form.

We chose cricothyroidostomy using the Rapid Four-Step Technique (RFST) because it is faster, more frequently performed and because it uses less materials than the standard technique. At time 1, the ideal cricothyroid membrane is identified by palpation. At time 2, one should perform the horizontal incision, 1 to $2 \mathrm{~cm}$ in the skin and the cricothyroid membrane with a scalpel. At time 3, before removal of the scalpel, a hook is placed that exerts traction in the caudal direction under the cartilage, thus stabilizing the larynx. In time 4, the tracheostomy tube is inserted into into the trachea.

Inclusion criteria: we included volunteer students from the first and second years of medical school at the Federal University of Paraná (UFPR).

Exclusion criteria: prior knowledge on the topic (students who had theoretical classes, surgical practice or who had accompanied the performance of cricothyroidostomy).

We established three study branches to assess knowledge acquisition and retention by students with no experience with the procedure (Figure 1). Through simple electronic randomization (Research Randomizer), students were allocated to one of the 3 groups ${ }^{34}$.

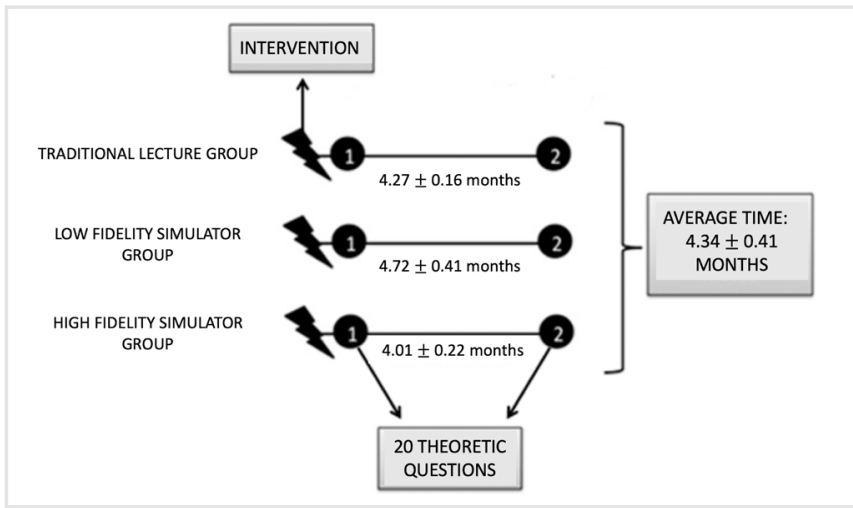

Figure 1. Methodology of intervention and evaluation of each group.

We calculated the sample size by setting the test power to $80 \%$ and significance level to $5 \%$. This calculation used the sample mean of each group, variance between groups equal to 10.86 , and assumed the variance within groups equal to 60 . Therefore, the minimum sample size for each group was 28 participants.

\section{Characteristics of the groups}

Group 1: The students attended a lecture given 
by a professor of the trauma surgery discipline of the UFPR surgery department. This professor was previously defined and did not participate in this project. In this way, the researcher's bias was canceled. The content of this class was a brief history of the procedure, materials, indications, surgical techniques (standard and RFST) and complications.

Group 2: The students attended a practical class with simulation of the procedure in a low-fidelity model, developed by the researcher himself.

Group 3: Students attended the practical class with simulation of the procedure on a high-fidelity Megacode Kelly Laerdal ${ }^{\circledR}$ mannequin ${ }^{35}$.

Classes (training) of groups 2 and 3 were offered by the same professor. This professor of the Training and Simulation discipline of the Department of Integrated Medicine of the UFPR Medical School also works in trauma care services. The structure of these classes was oral instruction (without audiovisual resources) with the same content as the lecture, followed by practical activity in the respective simulator model for each group. These classes were given at different times for each group.

The three classes' models lasted 20 minutes each, controlled by a digital timer. There was no contact between the members of each group.

\section{Learning assessment}

To assess the acquisition of knowledge right after the intervention, at the end of each class or training the participants took a test (P1) of 20 multiple choice questions (same for all groups), with only one correct alternative and of 30-minute resolution time. It covered indications, anatomical references, description of technical variants and possible complications within the surgical cricothyroidostomy theme. The test template was not made available and students were instructed not to study the topic until the second evaluation.

To assess knowledge retention, after 4 months students were submitted to a second knowledge test (P2) with the same content and number of questions, but with a different order of questions and their alternatives. This time interval was arbitrary, based on previous studies ${ }^{30}$.

\section{Low-fidelity cricothyroidostomy simulation model}

The materials used to build the simulator were: rectangular Medium Density Fiberboard (MDF) plates measuring $20 \times 10 \times 0.5 \mathrm{~cm}$, a foam block measuring $15 \times 9 \times 3 \mathrm{~cm}$, a $20 \mathrm{~cm}$ mechanical ventilator tube segment, pieces of Durepoxi ${ }^{\circledR}$ molded in the forms of the cricoid and thyroid cartilages, polyvinyl chloride (PVC) plastic film, a $27 \times 15 \mathrm{~cm}$-size segment of tattoo-training synthetic skin, and a size 10 rubber balloon (Figure 2a).

The low-fidelity simulator was developed from a previously created tracheostomy simulator ${ }^{36}$. Changes were made to simplify the assembly, reduce costs and allow the execution of the RFST cricothyroidostomy. The base is formed by two rectangular MDF plates perforated at the four ends, juxtaposed and fixed by screws and nuts. On the base, a rectangular foam block was glued to support the tube segment. On this structure, the mechanical ventilator tube segment was placed, allows the simulation of tracheal rings that can be palpated under the artificial skin. It also serves to fit the parts that represent the laryngeal cartilages and the balloon that simulates the lung.

The simulated pieces of the thyroid and cricoid cartilages, made of Durepoxy ${ }^{\circledR}$, had inserts on the back for fixation to the ventilator's tube, which were made respecting the size and anatomical position. At the location between the thyroid and cricoid cartilages, corresponding to the cricothyroid membrane, an opening of $1 \times 2.5 \mathrm{~cm}$ was made in the ventilator's tube to reproduce the cricothyroid space. This whole set was wrapped by five layers of PVC plastic film, to fix the pieces and simulate the cricothyroid membrane. The balloon was placed in the terminal portion of the ventilator's tube to simulate the lungs and thus allow the visualization of ventilation immediately after performing the cricothyroidostomy, with a 4.5 French size tracheostomy cannula. The synthetic skin was positioned to cover the entire simulator and was fixed bilaterally with the ends pressed between the two MDF boards.

The developed simulator allows the reproduction of RFST, which consists of skin incision with perforation of the cricothyroid membrane, positioning of the tracheostomy cannula (number 4.5) in the 
trachea, cuff insufflation, connection to the Artificial Manual Breathing Unit (AMBU®), and ventilation. When ventilated, the balloon allows to verity the success or failure of the procedure (Figure $2 b$ ).

Six simulators were produced for the study. All students performed the procedure with an intact skin on the simulator. Each low-fidelity simulator in 2019 cost US $\$ 4.00$, and each skin exchange, US\$ 0.90 , both funded by the researcher.
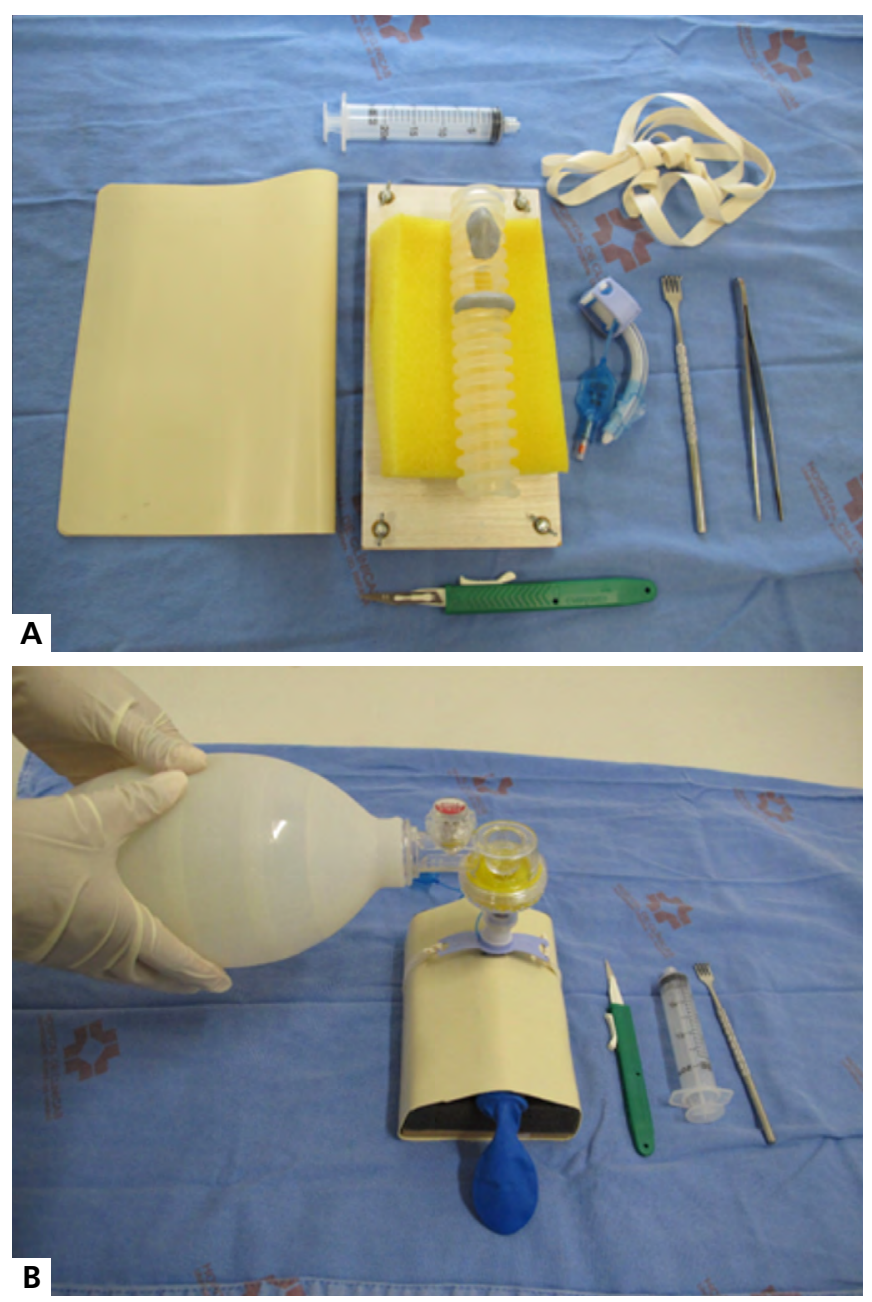

Figure 2. Simulador de cricotireoidostomia cirúrgica de baixa fidelidade. A. Low-fidelity surgical cricothyroidostomy simulator. B. Low-fidelity surgical cricothyroidostomy simulator.

\section{MegaCode Kelly Laerdal® high-fidelity simulator}

The MegaCode Kelly® high-fidelity simulator (Figure 3) was used in group 3. It is defined by the manufacturer as an advantageous mannequin for training a wide range of advanced life-saving skills ${ }^{35}$. The cost to purchase this mannequin in 2019 was approximately US\$ $7,500^{37}$.

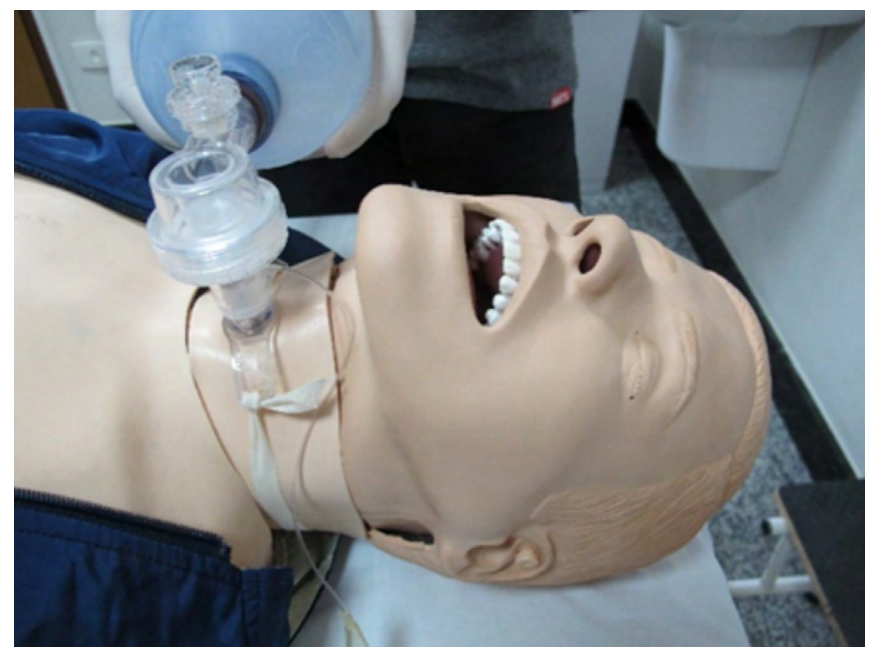

Figure 3. MegaCode Kelly® high-fidelity simulator.

\section{Statistical analysis}

We expressed the test scores (P1 and P2) as means and standard deviation (mean $\pm \mathrm{sd}$ ). We applied the Shapiro-Wilk test to assess the scores normality. We carried out a comparative analysis of the performances observed in each test between each of the study groups. For this purpose, we used the Analysis of Variance (ANOVA) with the effect of interaction between the factors: (i) tests (P1 and P2) and (ii) groups (lecture, lowfidelity or high-fidelity). The purpose of the analysis was to investigate possible differences in grades between the factors (groups and tests).

Then, we used a multiple comparison test (posthoc) with Bonferroni correction to assess differences within each factor. Statistical significance was considered when $p<0.05$. We performed the statistical analysis of the data using the statistical software R (R Core Team, 2019) version 3.6.1.

\section{RESULTS}

Each group contained 30 medical students, with no demographic differences between groups.

The average scores of the lecture, low fidelity model and high fidelity model groups in the first test were, respectively, 75.00, 76.09, and 68.79. In the 
second test, the average grades were, respectively, 69.84, 75.32, and 69.46. Table 1 shows the results of the scores in each test, for each group, expressed as mean \pm standard deviation .

Table 1. Average \pm standard deviation of students' scores by exam and group.

\begin{tabular}{|c|c|c|c|c|}
\hline Tests & Lecture & $\begin{array}{l}\text { Low } \\
\text { fidelity }\end{array}$ & $\begin{array}{l}\text { High } \\
\text { fidelity }\end{array}$ & p-value \\
\hline $\begin{array}{l}\text { Mean } \pm \\
\text { SD P1 * } \\
(n=90)\end{array}$ & $\begin{array}{r}75.00 \\
\pm 9.31\end{array}$ & $\begin{array}{r}76.09 \\
\pm 8.01\end{array}$ & $\begin{array}{r}68.79 \\
\pm 8.09\end{array}$ & $<0.05 * * *$ \\
\hline $\begin{array}{l}\text { Mean } \pm \\
\text { SD P2 ** } \\
(n=90)\end{array}$ & $\begin{array}{r}69.84 \\
\pm 9.79\end{array}$ & $\begin{array}{c}75.32 \\
\pm 12.03\end{array}$ & $\begin{array}{c}69.46 \\
\pm 11.96\end{array}$ & $>0.05$ \\
\hline
\end{tabular}

SD: standard deviation; ${ }^{*} P 1$ : test $1 ;{ }^{* *} P 2$ : test $2 ;{ }^{* * *} p<0.05$ (statistically significant difference).

It is possible to observe that the expository class group presented lower grades in P2 when compared to P1. In the other groups, the scores showed slight variations between $\mathrm{P} 1$ and $\mathrm{P} 2$.

After the ANOVA test, we conducted a multiple comparison test with the purpose of evaluating differences within each factor. Thus, as shown in table 2 , the group that attended the lecture was the only one that showed a significant difference between P1 and P2 $(p<0.05)$. The other groups did not present statistically significant differences between the tests ( $p>0.05$ ).

Table 3 presents the results of the multiple comparisons between the groups within each period.

he results presented in table 3 show that, when analyzing knowledge acquisition right after the intervention $(P 1)$, there was a difference $(p<0.05)$ between the lecture group and the high-fidelity one. In this comparison, the average observed in the lecture group was higher than that of high-fidelity model. There was also a statistical difference $(p<0.05)$ between the groups submitted to the simulation, with a higher average in the low-fidelity group than in the high-fidelity one. However, in P2, despite the different scores observed in Table 1, there was no statistically significant difference $(p>0.05)$ when comparing the groups in pairs.
Table 2. Intra-group comparison.

\begin{tabular}{|c|c|c|}
\hline Evidence & Groups & p-value \\
\hline $\mathrm{P} 1 * \times \mathrm{P} 2 * *$ & Lecture & $0.04 * * *$ \\
\hline $\mathrm{P} 1 * \times \mathrm{P} 2 * *$ & Low fidelity & 0.76 \\
\hline $\mathrm{P} 1 * \times \mathrm{P} 2 * *$ & High fidelity & 0.79 \\
\hline \multicolumn{3}{|c|}{$\begin{array}{l}{ }^{*} P 1: \text { test } 1 ;{ }^{*} P 2 \text { : test } 2 ;{ }^{* * *} p<0.05 \text { (statistically significant diffe- } \\
\text { rence). }\end{array}$} \\
\hline
\end{tabular}

Table 3. Inter-group comparison.

\begin{tabular}{|c|c|c|}
\hline Evidence & Comparison by groups & $p$-value \\
\hline \multirow{3}{*}{$\mathrm{P} 1$ * } & Lecture x Low fidelity & 1,00 \\
\hline & Lecture $x$ High fidelity & $0.04 * * *$ \\
\hline & Low fidelity $x$ High fidelity & $0.01 * * *$ \\
\hline \multirow{3}{*}{$P 2 * *$} & Lecture $x$ Low fidelity & 0.09 \\
\hline & Lecture $x$ High fidelity & 1.00 \\
\hline & Low fidelity $x$ High fidelity & 0.07 \\
\hline
\end{tabular}

$\overline{\star P 1}$ : test $1 ;{ }^{* \star} P 2:$ test $2 ;{ }^{* * *} p<0.05$ (statistically significant difference).

\section{DISCUSSION}

In this study, we evaluated the learning of by inexperienced students, comparing the lecture with simulation in low and high-fidelity models.

We chosen cricothyroidostomy as the study object because it is an infrequent procedure and seldom practiced by professionals and students, but crucial as a last oxygen supply option, threatening the patient's life if not performed properly 38,39 . This study and that of Kennedy et al. demonstrated that training programs in advanced, simulation-based airway management are more effective 
than expository or video classes $^{40}$.

Although the lecture is the most common method of teaching ${ }^{1}$, we found less retention of learning by it. The literature confirms the best result in retaining knowledge with the evaluated models, and even reinforces the need to break paradigms in face of the traditional teaching method for acquiring knowledge and motor and behavioral skills ${ }^{9,31}$. Hubert et al. also demonstrated the superiority of simulation when the target audience is made up of professionals already working in the covered area $^{41}$. Knowledge retention in the long run is especially important in emergency situations, for decision making must be quick and assertive to ensure a good prognosis for the patient ${ }^{30,42}$.

The major impediment to the mass implementation of simulation methods in medical education is still the cost ${ }^{2,19}$. The cost of acquiring highfidelity simulators and maintaining realistic simulation centers made simulation a good method for learning, but questionable from a financial point of view².

This research described the costs involved in the different simulators. The cost of the high-fidelity mannequin was US\$7,50037, and the model developed by the researcher cost approximately US\$5.00, including the artificial skin replacement performed in each procedure. Low-cost models have the benefit of repeated training, without worrying about the replacement price of any item, as they are easily accessible, allowing learning according to the student's individual needs $22,28,43$.

In this research, as well as in that of Massoth et al., who evaluated different degrees of fidelity in advanced life support training, the group exposed to the low-fidelity model had the average score higher than the average of the group exposed to the high-fidelity one. In other words, both in the teaching of integrative abilities and in the directed tasks observed in this study, the low-fidelity simulation was not inferior to the high-fidelity simulation ${ }^{29}$.

It is possible that the poor results with the highfidelity model have occurred due to the presence of excess distractions in these models. These become irrelevant in the learning of inexperienced students and drive attention away from the main points to be fixed ${ }^{44}$. The high levels of stress and anxiety of students are similar to real daily practice; therefore, the use of low-fidelity models, with more specific goals, is more effective for less experienced students ${ }^{45}$. According to the cognitive load theory, working memory is limited in relation to the amount of information that can be retained versus the number of operations that can be performed. By the time the student is involved in learning a new task, the working memory is occupied with the processing of relevant information. In a second stage of this study, we will analyze learning and retention when students attend and practice, at the same time, skills taught in other surgical procedures.

This increase in information results in an overload of the cognitive processing system. Attention resources are scarce and can lead to incomplete, inefficient or deficient learning ${ }^{46}$.

Thus, there is a possibility that for inexperienced students, learning is not compromised with the use of low-fidelity mannequins, or it may even be improved. Therefore, we conclude that RFST cricothyroidostomy training for inexperienced students is feasible using a lowfidelity simulator.

\section{R E S U M O}

Objetivo: comparar a aquisição e retenção de conhecimento, sobre cricotireoidostomia cirúrgica pela técnica rápida de quatro tempos (TRQT), quando ensinada por aula expositiva, simulação de baixa fidelidade e de alta fidelidade. Métodos: noventa alunos de medicina da UFPR dos primeiros anos foram randomizados em 3 grupos: 1) aula expositiva, 2) simulador de baixa fidelidade, ou 3) simulador de alta fidelidade (comercial). O tema exposto foi a cricotireoidostomia cirúrgica pela técnica rápida de quatro tempos (TRQT). Logo após as aulas, os grupos foram submetidos a uma prova de múltipla escolha com 20 questões (P1). Quatro meses após, realizaram uma outra prova (P2), com conteúdo similar. Análise de Variância foi usada para comparar as notas de cada grupo na P1 com suas notas na P2, e as notas dos 3 grupos de 2 a 2 na $P 1$ e na P2. Utilizou-se um teste de comparações múltiplas (post-hoc) para verificar diferenças dentro de cada fator (prova e grupo). Considerou-se significância estatística quando $p<0,05$. A análise estatística foi feita no software estatístico $R$ versão 3.6.1. Resultados: cada grupo foi composto de 30 estudantes de medicina, sem diferenças demográficas entre os grupos. As notas médias dos grupos da aula expositiva, do modelo de baixa fidelidade e de alta fidelidade na P1 foram, respectivamente, 75,00, 76,09 , e 68,79, (p<0,05). Na P2 as notas foram respectivamente 69,84, 75,32, 69,46, (p>0,05). Conclusão: a simulação de baixa fidelidade foi mais eficaz no aprendizado e na retenção de conhecimento, sendo viável para o treinamento de cricotireoidostomia TRQT em alunos inexperientes.

Palavras chave: Treinamento por Simulação. Educação Médica. Medicina de Emergência. Manuseio das Vias Aéreas. Cartilagem Cricoide. 


\section{REFERENCES}

1. Diesel A, Baldez A, Martins S. Os princípios das metodologias ativas de ensino: uma abordagem teórica. Rev Thema. 2017;14(1):268-88.

2. Iglesias $A G$, Pazin-Filho $A$. Emprego de simulações no ensino e na avaliação. Med. 2015;48(3):233-40.

3. Costa RRO, Medeiros SM, Martins JCA, Cossi MS, Araújo MS. Percepção de estudantes da graduação em enfermagem sobre a simulação realística. Rev Cuid. 2017;8(3):1799-808.

4. Boet $S$, Bould MD, Fung L, Qosa H, Perrier L, Tavares $W$, et al. Transfer of learning and patient outcome in simulated crisis resource management: A systematic review. Can J Anesth. 2014;61(6):571-82.

5. Elsey EJ, Griffiths G, Humes DJ, West J. Meta-analysis of operative experiences of general surgery trainees during training. Br J Surg. 2017;104(1):22-33.

6. Committee on Surgical Training. Certification Guidelines for General Surgery [Internet]. London: JCST;C [upadate 2017 Jul 15]. Available from: https://www.jcst.org/search/? $\mathrm{q}=$ Certification+Guidelines+for+General+Surgery+.

7. Zerhouni YA, Abu-bonsrah N, Mehes M, Goldstein S, Buyske J, Abdullah F. Surgical Human Resources for Health General surgery education : a systematic review of training. Lancet [Internet]. 385:\$39. Available from: http://dx.doi.org/10.1016/S01406736(15)60834-0

8. Cook DA, Brydges R, Hamstra SJ, Zendejas B, Szostek $\mathrm{JH}$, Wang AT, et al. Comparative effectiveness of technology-enhanced simulation versus other instructional methods: A systematic review and meta-analysis. Simul Healthc. 2012;7(5):308-20.

9. Motta EV da, Baracat EC. Treinamento de habilidades cirúrgicas para estudantes de medicina - papel da simulação. Rev Med. 2018;97(1):18.

10. Iverson K, Riojas R, Sharon D, Hall AB. Objective comparison of animal training versus artificial simulation for initial cricothyroidotomy training. Am Surg. 2015;81(5):515-8.

11. Makowski AL. The Ethics of Using the Recently Deceased to Instruct Residents in Cricothyrotomy. Ann Emerg Med [Internet]. 2015;66(4):403-8. Available from: http://dx.doi.org/10.1016/j. annemergmed.2014.11.019

12. Cox T, Seymour N, Stefanidis D. Moving the Needle: Simulation's Impact on Patient Outcomes. Surg Clin North Am. 2015;95(4):827-38.

13. Acton RD. The Evolving Role of Simulation in Teaching Surgery in Undergraduate Medical Education. Surg Clin North Am [Internet]. 2015;95(4):73950. Available from: http://dx.doi.org/10.1016/j. suc.2015.04.001

14. Nabavi A, Schipper J. Op.-Simulation in der Chirurgie. HNO. 2017;65(1):7-12.

15. Aho JM, Thiels CA, Aljamal YN, Ruparel RK, Rowse $P G$, Heller SF, et al. Every surgical resident should know how to perform a cricothyrotomy: An inexpensive cricothyrotomy task trainer for teaching and assessing surgical trainees. J Surg Educ [Internet]. 2015;72(4):658-61. Available from: http://dx.doi. org/10.1016/j.jsurg.2014.12.012

16. Cooper JB, Taqueti VR. A brief history of the development of mannequin simulators for clinical education and training. Postgrad Med J. 2008;84(997):563-70.

17. Kurashima $Y$, Hirano $S$. Systematic review of the implementation of simulation training in surgical residency curriculum. Surg Today. 2017;47(7):77782.

18. Bjerrum F, Thomsen ASS, Nayahangan LJ, Konge L. Surgical simulation: Current practices and future perspectives for technical skills training. Med Teach [Internet]. 2018;40(7):668-75. Available from: https://doi.org/10.1080/0142159X.2018.1472754

19. Johnston MJ, Paige JT, Aggarwal R, Stefanidis D, Tsuda S, Khajuria A, et al. An overview of research priorities in surgical simulation: What the literature shows has been achieved during the 21st century and what remains. Am J Surg [Internet]. 2016;211(1):214-25. Available from: http://dx.doi. org/10.1016/j.amjsurg.2015.06.014

20. Moglia A, Ferrari V, Morelli L, Ferrari M, Mosca F, Cuschieri A. A Systematic Review of Virtual Reality Simulators for Robot-assisted Surgery. Eur Urol [Internet]. 2016;69(6):1065-80. Available from: http://dx.doi.org/10.1016/j.eururo.2015.09.021

21. Chauvin SW. Applying educational theory to Simulation-based training and assessment in Surgery. 
Surg Clin North Am [Internet]. 2015;95(4):695715. Available from: http://dx.doi.org/10.1016/j. suc.2015.04.006

22. Denadai R, Saad-Hossne R, Todelo AP, Kirylko L, Souto LRM. Modelos de bancada de baixa fidelidade para o treinamento de habilidades cirúrgicas básicas durante a graduação médica. Rev Col Bras Cir. 2014;41(2):137-45.

23. Finnerty BM, Afaneh C, Aronova A, Fahey TJ, Zarnegar R. General surgery training and robotics: Are residents improving their skills? Surg Endosc. 2016;30(2):567-73.

24. Adams AJ, Wasson EA, Admire JR, Pablo Gomez $P$, Babayeuski RA, Sako EY, et al. A comparison of teaching modalities and fidelity of simulation levels in teaching resuscitation scenarios. J Surg Educ [Internet]. 2015;72(5):778-85. Available from: http://dx.doi.org/10.1016/j.jsurg.2015.04.011

25. Cheng A, Lockey A, Bhanji F, Lin Y, Hunt EA, Lang $E$. The use of high-fidelity manikins for advanced life support training-A systematic review and metaanalysis. Resuscitation [Internet]. 2015;93:1429. Available from: http://dx.doi.org/10.1016/j. resuscitation.2015.04.004

26. Hart D, Nelson J, Moore J, Gross E, Oni A, Miner J. Shoulder Dystocia Delivery by Emergency Medicine Residents: A High-fidelity versus a Novel Low-fidelity Simulation Model-A Pilot Study. AEM Educ Train. 2017;1(4):357-62.

27. Hossien A. Low-fidelity simulation of mitral valve surgery: Simple and effective trainer. J Surg Educ [Internet]. 2015;72(5):904-9. Available from: http:// dx.doi.org/10.1016/j.jsurg.2015.04.010

28. Katayama A, Nakazawa H, Tokumine J, Lefor AK, Watanabe K, Asao T, et al. A high-fidelity simulator for needle cricothyroidotomy training is not associated with increased proficiency compared with conventional simulators: A randomized controlled study. Medicine (Baltimore). 2019;98(8):e14665.

29. Massoth C, Röder $H$, Ohlenburg $H$, Hessler $M$, Zarbock A, Pöpping DM, et al. High-fidelity is not superior to low-fidelity simulation but leads to overconfidence in medical students. BMC Med Educ. 2019;19(1):1-8.

30. Mizubuti GB, Allard RV, Ho AM, Wang L, Beesley
T, Hopman WM, et al. Knowledge retention after focused cardiac ultrasound training: a prospective cohort pilot study. Brazilian J Anesthesiol [Internet]. 2019;69(2):177-83. Available from: https://doi. org/10.1016/j.bjan.2018.10.002

31. Nimbalkar A, Patel D, Kungwani A, Phatak A, Vasa R, Nimbalkar $S$. Randomized control trial of high fidelity vs low fidelity simulation for training undergraduate students in neonatal resuscitation Medical Education. BMC Res Notes. 2015;8(1).

32. O'Leary JA, Nash R, Lewis PA. High fidelity patient simulation as an educational tool in paediatric intensive care: A systematic review. Nurse Educ Today [Internet]. 2015;35(10):e8-12. Available from: http://dx.doi.org/10.1016/j.nedt.2015.07.025

33. Sarmah P, Voss J, Ho A, Veneziano D, Somani B. Low vs. high fidelity: The importance of "realism" in the simulation of a stone treatment procedure. Curr Opin Urol. 2017;27(4):316-22.

34. EUA. Research Randomizer [internet]. [cited 2020 Jan 31]. Available from: https://www.randomizer. org/

35. EUA. Laerdal Medical - Helping Save Lives [internet]. MegaCode Kelly®. [cited 2020 Jan 31]. Available from: https://www.laerdal.com/br/products/ simulation-training/emergency-care-trauma/ megacode-kelly/

36. Temperly KS, Yaegashi CH, Silva AML, Novak EM. Desenvolvimento e validação de um simulador de traqueostomia de baixo custo. Sci Med. 2018;28(1):ID28845. http://doi.org/10.15448/19806108. 2018.1.28845

37. EUA. Health Services. [internet]. Resusci Anne Advanced Skill Trainer [cited 2020 Jan 31]. Available from: https://www.schoolhealth.com/resusci-anneadvanced-skill-trainer.

38. Kovacs G, Sowers N. Airway Management in Trauma. Emerg Med Clin North Am [Internet]. 2018;36(1):61-84. Available from: https://doi. org/10.1016/j.emc.2017.08.006

39. Melchiors J, Todsen T, Nilsson P, Wennervaldt K, Charabi B, Bøttger $M$, et al. Preparing for emergency: A valid, reliable assessment tool for emergency cricothyroidotomy skills. Otolaryngol Head Neck Surg. 2015;152(2):260-5. 
40. Kennedy CC, Cannon EK, Warner DO, Cook DA. Advanced airway management simulation training in medical education: A systematic review and metaanalysis. Crit Care Med. 2014;42(1):169-78.

41. Hubert V, Duwat A, Deransy R, Mahjoub Y, Dupont $H$. Effect of simulation training on compliance with difficult airway management algorithms, technical ability, and skills retention for emergency cricothyrotomy. Anesthesiology. 2014;120(4):9991008.

42. Veenstra BR, Wojtowicz A, Walsh N, Velasco JM. The emergency surgical airway: Bridging the gap from quality outcome to performance improvement through a novel simulation based curriculum. Am J Surg [Internet]. 2019;217(3):562-5. Available from: https://doi.org/10.1016/j.amjsurg.2018.09.026

43. Gauger VT, Rooney D, Kovatch KJ, Richey L, Powell $A$, Berhe $H$, et al. A multidisciplinary international collaborative implementing low cost, high fidelity 3D printed airway models to enhance Ethiopian

Received in: 02/03/2020

Accepted for publication: 26/03/2020

Conflict of interest: no.

Funding source: none. anesthesia resident emergency cricothyroidotomy skills. Int J Pediatr Otorhinolaryngol [Internet]. 2018;114(July):124-8. Available from: https://doi. org/10.1016/j.ijporl.2018.08.040

44. Núñes IR, Araos DZ, Delgado CM. Efeitos do treinamento muscular respiratório domiciliar em crianças e adolescentes com doença pulmonar crônica. J Bras Pneumol. 2014;40(6):58-71.

45. Georgiou K, Larentzakis A, Papavassiliou AG. Surgeons' and surgical trainees' acute stress in real operations or simulation: A systematic review. Surgeon [Internet]. 2017;15(6):355-65. Available from: http://dx.doi.org/10.1016/j.surge.2017.06.003

46. Sewell $\mathrm{JL}$, Maggio LA, ten Cate $O$, van Gog $T$, Young JQ, O'Sullivan PS. Cognitive load theory for training health professionals in the workplace: A BEME review of studies among diverse professions: BEME Guide No. 53. Med Teach [Internet]. 2019;41(3):256-70. Available from: https://doi. org/10.1080/0142159X.2018.1505034

\section{Mailing address:}

Akihito Inca Atahualpa Urdiales

E-mail: aiaurdiales@uol.com.br/dr.phillipeabreu@gmail.com 